\title{
Development of a real-time PCR for the specific detection of Waddlia chondrophila in clinical samples
}

\author{
G. Goy • A. Croxatto • K. M. Posfay-Barbe • \\ A. Gervaix • G. Greub
}

Received: 9 June 2009 / Accepted: 13 August 2009 /Published online: 2 September 2009

(C) Springer-Verlag 2009

\begin{abstract}
Waddlia chondrophila is considered as an emerging human pathogen likely involved in miscarriage and lower respiratory tract infections. Given the low sensitivity of cell culture to recover such an obligate intracellular bacteria, molecular-based diagnostic approaches are warranted. We thus developed a real-time PCR that amplifies Waddlia chondrophila DNA. Specific primers and probe were selected to target the 16S rRNA gene. The PCR specifically amplified $W$. chondrophila but did not amplify other related-bacteria such as Parachlamydia acanthamoebae, Simkania negevensis and Chlamydia pneumoniae. The PCR exhibited a good intra-run and inter-run reproducibility and a sensitivity of less than ten copies of the positive control. This real-time PCR was then applied to 32 nasopharyngeal aspirates taken from children with bronchiolitis not due to respiratory syncytial virus (RSV). Three samples revealed to be Waddlia positive, suggesting a possible role of this Chlamydia-related bacteria in this setting.
\end{abstract}

\section{Introduction}

During the last 15 years, several Chlamydia-related bacteria have been discovered [1-3]. Among them, Simkania negevensis and Parachlamydia acanthamoebae seem to

G. Goy $\cdot$ A. Croxatto $\cdot$ G. Greub $(\bowtie)$

Center for Research on Intracellular Bacteria,

Institute of Microbiology,

University Hospital Center and University of Lausanne,

1011 Lausanne, Switzerland

e-mail: gilbert.greub@chuv.ch

K. M. Posfay-Barbe $\cdot$ A. Gervaix

Children's Hospital of Geneva, University Hospitals of Geneva,

Geneva, Switzerland be implicated in bronchiolitis in children and pneumonia in adults $[4,5]$. Waddlia chondrophila was isolated twice from aborted bovine fetuses $[6,7]$ and a seroepidemiological study revealed a strong association between $W$. chondrophila seropositivity and miscarriage in humans [8]. In addition, DNA of $W$. chondrophila was amplified from the sputum of a patient suffering from pneumonia [9]. Moreover, W. chondrophila showed rapid replication in human macrophages [10]. Detection of this obligate intracellular bacterium is limited by its inability to grow on axenic media. We thus developed a real-time diagnostic PCR assay to specifically detect $W$. chondrophila DNA and applied it to samples from patients with bronchiolitis.

\section{Material and methods}

Using Primer3 software [11], a forward primer WadF4 (5'GGCCCTTGGGTCGTAAAGTTCT-3'), a reverse primer WadR4 (5'CGGAGTTAGCCGGTGCTTCT-3') and a probe WadS2 (5'-FAM-CATGGGAACAAGAGAAGGATGBHQ-3') were selected to amplify a 101-bp fragment of the 16S rRNA gene of both $W$. chondrophila strains available to date: strain ATCC VR-1470 (LGC Promochem, Molsheim, France) and strain 2032/99 (K. Sachse, Jena, Germany). The probe contained locked nucleic acids (underlined in sequence above).

Both strains were grown in Acanthamoeba castellanii ATCC 30010 and purified on sucrose and gastrographin, as previously described [12]. Bacterial DNA was then extracted using QIAamp DNA Mini kit (Qiagen, Hilden, Germany). A 16S rRNA gene plasmid positive control was constructed using primers WadF3 (5'-CAGTCGA GAATCTTTCGCAAT-3') and WadR4, as described [13]. 
Table 1 Bacterial species used to test the specificity of the Waddlia real-time PCR a Kindly provided by J. Storz, Baton Rouge Louisiana, LA, USA

b Kindly provided by G.E. Jones, Moredun Research Institute, Edinburgh, UK

c Kindly provided by R.K. Hoop, Zürich, Switzerland

${ }^{d}$ Kindly provided by A. Pospischil, Zürich, Switzerland

e Kindly provided by Christian Durussel, Lausanne, Switzerland

\begin{tabular}{ll}
\hline Bacterial species & Source/strain \\
\hline Bacteroides fragilis & ATCC25825 \\
Chlamydia suis & $\mathrm{S} 45 / 6^{\mathrm{a}}$ \\
Chlamydia abortus & $\mathrm{S} 26 / 3^{\mathrm{b}}$ \\
Chlamydia pecorum & $\mathrm{W}^{\mathrm{a}}$ \\
Chlamydia psittaci & T49/90 ${ }^{\mathrm{c}}$ \\
Chlamydia pneumoniae & K6 ${ }^{\mathrm{d}}$ \\
Criblamydia sequanensis & CRIB-18 \\
Escherichia coli & ATCC 25922 \\
Haemophilus influenzae & ATCC 49247 \\
Legionella pneumophila & Clinical specimen \\
Moraxella catharralis & Clinical specimen \\
Neochlamydia hartmannellae & ATCC 50802 \\
Parachlamydia acanthamoebae strain BN9 & ATCC VR-1476 \\
Parachlamydia acanthamoebae strain Hall's coccus & ATCC VR-1476 \\
Protochlamydia amoebophila strain UWE25 & ATCC PRA-7 \\
Pseudomonas aeruginosa & ATCC 27853 \\
Rhabdochlamydia crassificans & CRIB-01 \\
Simkania negevensis & ATCC VR-1471 \\
Staphylococcus aureus & ATCC 25923 \\
Streptococcus mitis & ATCC 6249 \\
\hline & \\
\hline
\end{tabular}

PCR reactions were performed with $0.2 \mu \mathrm{M}$ of each primer, $0.1 \mu \mathrm{M}$ of probe and iTaq supermix with ROX (BioRad, Reinach, Switzerland). Cycling conditions were $2 \mathrm{~min}$ at $50^{\circ} \mathrm{C}, 3 \mathrm{~min}$ at $95^{\circ} \mathrm{C}$ followed by 45 cycles of $15 \mathrm{~s}$ at $95^{\circ} \mathrm{C}$ and $1 \mathrm{~min}$ at $60^{\circ} \mathrm{C}$. Amplification and detection of PCR products were performed with $\mathrm{ABI}$ Prism 7000 (Applied Biosystems, Foster City, USA). To assess the analytical specificity of this new real-time PCR, we tested DNA extracted from 20 different bacterial strains (Table 1). We also tested DNA of $A$. castellanii ATCC 30010 and human DNA (Roche Diagnostics, Mannheim, Germany). A PCR inhibition control (4 $\mu$ l DNA spiked with $1 \mu$ l positive control) was used for all these DNA to verify that absence of amplification was due to the specificity of the PCR and not to the presence of PCR inhibitors. To assess the analytical sensitivity, 10fold serial dilutions $\left(10^{5}\right.$ to $10^{0}$ copies $)$ of the positive plasmid control were tested in duplicates in 15 different runs.

Intra-run reproducibility was assessed on 75 duplicates by plotting the $\mathrm{Ct}$ (threshold cycle) values of both duplicates against each other on a graph, by plotting the differences between both duplicates against the mean of each duplicate and by calculating the $95 \%$ confidence interval using the Bland-Altman algorithm (GraphPad 5.0). To assess the inter-run reproducibility, the mean $\mathrm{Ct}$ of duplicates obtained in 15 independent runs were compared for each concentration of plasmid DNA.

\section{Results and discussion}

Genomic DNA of the two Waddlia strains available in coculture were successfully amplified by this 16S rRNA gene real-time PCR with $\mathrm{Ct}$ values of 19 when samples with approximately $10^{5}$ DNA copies/ $\mu$ l were tested. The analytical sensitivity of the real-time PCR was of about ten copies of plasmid control DNA. Indeed, when testing ten-fold dilutions of plasmid, nine of 15 replicates were positive at a concentration of one copy whereas all 15 replicates were positive at a concentration of ten copies. Although the assay is essentially based on the specificity of the probe, analytical specificity was high. No crossamplification was observed when testing microorganisms listed in Table 1, which indicates that the specificity of the probe ensured a high degree of discrimination between the amplicons of Waddlia chondrophila and those of the other tested bacteria. Intra-run reproducibility was high as shown

Fig. 1 a Plot of cycle threshold $(\mathrm{Ct})$ values of first duplicate versus second duplicate showing intra-run reproducibility. The solid line represents the linear regression whereas the dashed lines represent the $95 \%$ prediction interval. b Bland-Altman graph representing the $\mathrm{Ct}$ difference between both duplicates according to the average $\mathrm{Ct}$ of duplicates. The dashed line represents the $95 \%$ confidence interval (CI $95 \%$ ). c Inter-run and intra-run reproducibilities assessed using $10^{1}$ to $10^{5}$ positive control plasmid copies in 15 successive runs. Error bars represent the standard error of the mean of duplicates (intra-run reproducibility) 

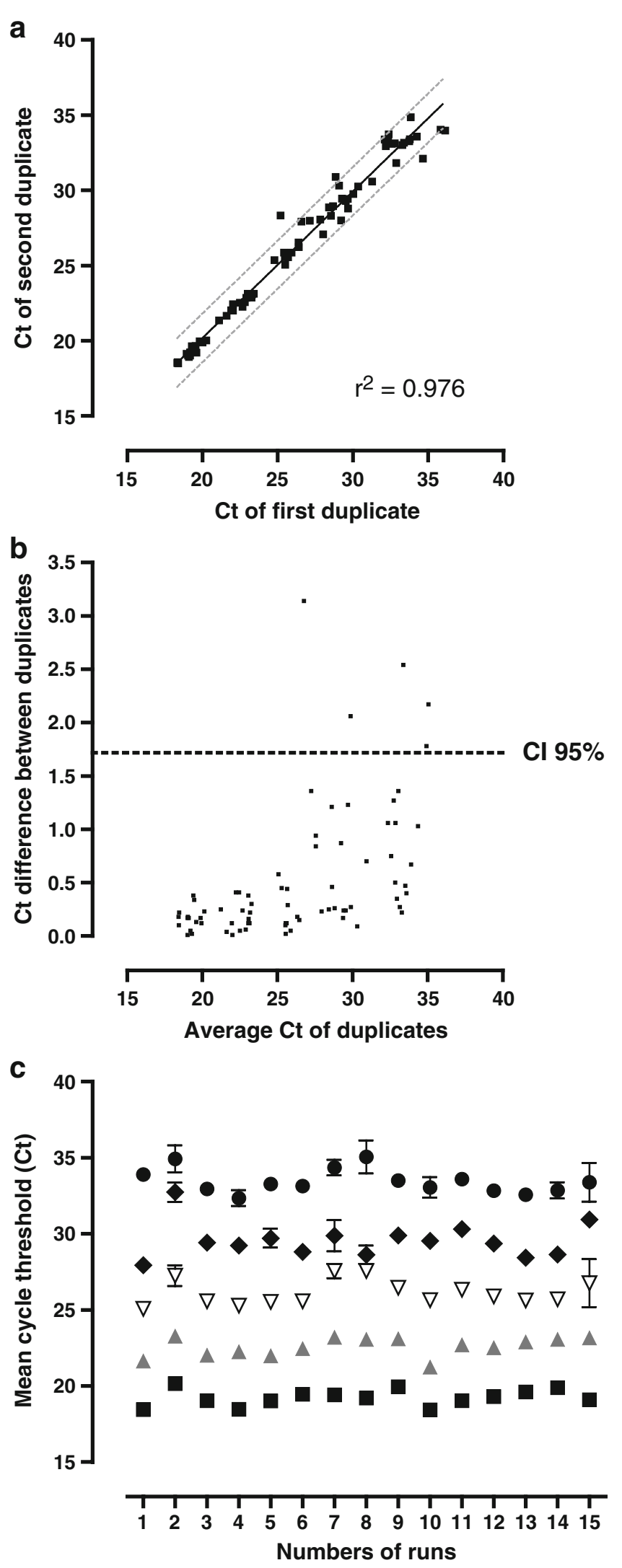

- $10^{1}$ copies $/ \mu \mathrm{l} \bullet 10^{2}$ copies $/ \mu \mathrm{l} \quad \nabla 10^{3}$ copies $/ \mu \mathrm{l}$ $\Delta 10^{4}$ copies $/ \mu \mathrm{l}$ - $10^{5}$ copies $/ \mu \mathrm{l}$

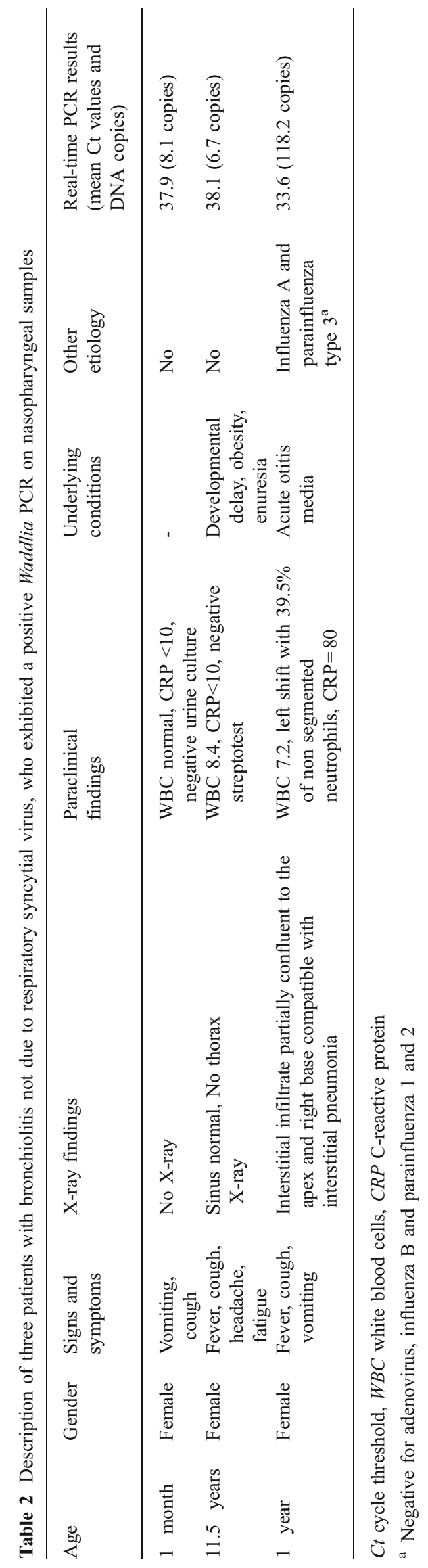


in Fig. 1, with $\mathrm{Ct}$ of both duplicates being relatively similar with a correlation coefficient $r^{2}$ of 0.976 (Fig. 1a). In Fig. 1b, the Bland-Altman graph revealed that the $95 \%$ confidence interval was 1.72 cycles. Inter-run reproducibility is shown in Fig. 1c. The standard deviation values reflect small deviation from the mean and indicate good reproducibility among different runs. Thus, the quantification was highly reliable from $10^{1}$ to $10^{5}$ copies, with an average difference of 3 cycles per ten-fold dilution (Fig. 1c).

The sensitivity of this $W$. chondrophila real-time PCR, which was less than ten copies, is excellent and comparable to other diagnostic TaqMan PCR assays $[14,15]$. This realtime PCR is more sensitive than the 16SigF-Rp2Chlam broad range PCR [16], which only detects about 1,000 copies of DNA [14]. Thus, this real-time PCR allows detection of Waddlia DNA not detectable by classical PCR. This increased sensitivity is likely a result of the real-time technology, which combines amplification of small length amplicons and detection with an highly sensitive fluorescent probe.

As the role of $W$. chondrophila in lower respiratory tract infections is possible [9], we applied our real-time PCR to 32 nasopharyngeal aspirates from children with bronchiolitis not due to respiratory syncytial virus (RSV), which is the most common etiology of bronchiolitis. Waddlia DNA was detected in three samples. The characteristics of these three patients are summarized in Table 2. Briefly, these three female patients all exhibited symptoms of bronchiolitis. Another microbial etiology was identified in one of the three patients.

In conclusion, we developed a new $W$. chondrophila realtime PCR. The assay revealed to be specific with a very low detection limit and its application to clinical samples allowed detection of $W$. chondrophila DNA in three samples taken from children with bronchiolitis. However, more patients should be investigated in order to confirm a possible role of $W$. chondrophila in bronchiolitis. In the future, our Waddlia diagnostic PCR could be useful to define the role of Waddlia in other human diseases, such as pneumonia and miscarriage. Since the format of this real-time PCR assay is compatible with 384-well plates, the test will also be useful for screening large numbers of samples to investigate the public health risk of this amoeba-resisting bacterium.

Acknowledgements We thank Sébastien Aeby and Nicola Casson for technical help. This project was funded by Swiss National Science Foundation (SNSF) grant number 3200BO-116445. Gilbert Greub is supported by the Leenards Foundation through a career award entitled "Bourse Leenards pour la relève académique en médecine clinique à Lausanne".

\section{References}

1. Greub G, Raoult D (2002) Parachlamydiaceae: potential emerging pathogens. Emerg Infect Dis 8(6):625-630

2. Corsaro D, Feroldi V, Saucedo G, Ribas F, Loret JF, Greub G (2009) Novel Chlamydiales strains isolated from a water treatment plant. Environ Microbiol 11(1):188-200. doi:10.1111/j.14622920.2008.01752.x

3. Everett KD, Andersen AA (1997) The ribosomal intergenic spacer and domain I of the 23S rRNA gene are phylogenetic markers for Chlamydia spp. Int J Syst Bacteriol 47(2):461-473

4. Friedman MG, Dvoskin B, Kahane S (2003) Infections with the chlamydia-like microorganism Simkania negevensis, a possible emerging pathogen. Microbes Infect 5(11):1013-1021. doi:10.1016/ S1286-4579(03)00188-6

5. Greub G (2009) Parachlamydia acanthamoebae, an emerging agent of pneumonia. Clin Microbiol Infect 15(1):18-28. doi:10.1111/j.1469-0691.2008.02633.x

6. Dilbeck PM, Evermann JF, Crawford TB, Ward AC, Leathers CW, Holland CJ, Mebus CA, Logan LL, Rurangirwa FR, McGuire TC (1990) Isolation of a previously undescribed rickettsia from an aborted bovine fetus. J Clin Microbiol 28 (4):814-816

7. Henning K, Schares G, Granzow H, Polster U, Hartmann M, Hotzel H, Sachse K, Peters M, Rauser M, Henning K, Schares G, Granzow H, Polster U, Hartmann M, Hotzel H, Sachse K, Peters M, Rauser M (2002) Neospora caninum and Waddlia chondrophila strain 2032/99 in a septic stillborn calf. Vet Microbiol 85 (3):285-292. doi:10.1016/S0378-1135(01)00510-7

8. Baud D, Thomas V, Arafa A, Regan L, Greub G (2007) Waddlia chondrophila, a potential agent of human fetal death. Emerg Infect Dis 13(8):1239-1243

9. Haider S, Collingro A, Walochnik J, Wagner M, Horn M (2008) Chlamydia-like bacteria in respiratory samples of communityacquired pneumonia patients. FEMS Microbiol Lett 281(2):198202. doi:10.1111/j.1574-6968.2008.01099.x

10. Goy G, Croxatto A, Greub G (2008) Waddlia chondrophila enters and multiplies within human macrophages. Microbes Infect 10 (5):556-562. doi:10.1016/j.micinf.2008.02.003

11. Rozen S, Skaletsky H (2000) Primer3 on the WWW for general users and for biologist programmers. Methods Mol Biol 132:365386

12. Casson N, Medico N, Bille J, Greub G (2006) Parachlamydia acanthamoebae enters and multiplies within pneumocytes and lung fibroblasts. Microbes Infect 8(5):1294-1300. doi:10.1016/j. micinf.2005.12.011

13. Casson N, Michel R, Muller KD, Aubert JD, Greub G (2008) Protochlamydia naegleriophila as etiologic agent of pneumonia. Emerg Infect Dis 14(1):168-172

14. Casson N, Posfay-Barbe KM, Gervaix A, Greub G (2008) New diagnostic real-time PCR for specific detection of Parachlamydia acanthamoebae DNA in clinical samples. J Clin Microbiol 46 (4):1491-1493. doi:10.1128/JCM.02302-07

15. Jaton K, Bille J, Greub G (2006) A novel real-time PCR to detect Chlamydia trachomatis in first-void urine or genital swabs. J Med Microbiol 55(12):1667-1674. doi:10.1099/jmm.0.46675-0

16. Thomas V, Herrera-Rimann K, Blanc DS, Greub G (2006) Biodiversity of amoebae and amoeba-resisting bacteria in a hospital water network. Appl Environ Microbiol 72(4):24282438. doi:10.1128/AEM.72.4.2428-2438.2006 